\title{
Factors related to lower functional capacity of institutionalized older adults
}

\author{
Fatores relacionados à capacidade funcional reduzidla em idosos institucionalizados \\ Factores relacionados con la reducción de la capacidad funcional en ancianos institucionalizados
}

Received: 05/18/2021 | Reviewed: 05/28/2021 | Accept: 05/30/2021 | Published: 06/14/2021

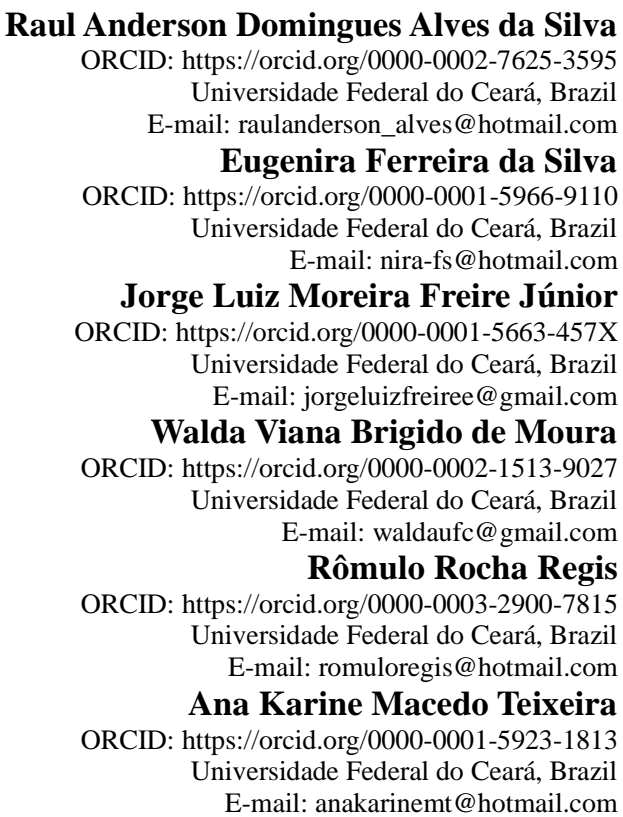

\begin{abstract}
The aim of this study was to assess the functional capacity of institutionalized older people and to verify which sociodemographic, health factors and oral health were related to the worse ability to perform daily activities. It was a cross-sectional study conducted with 512 institutionalized elderly people. Sociodemographic profile; general health and oral health conditions were evaluated. Functional capacity was assessed by Barthel Index. A high prevalence of functional dependent elderly was found $(47.1 \%)$. A lower functional capacity was associated with female $(p=0.006)$; higher education $(p=0.009)$; older elderly $(p<0.045)$; decision to institutionalize by others $(p=0.011)$; affected cognitive state $(\mathrm{p}<0.001)$; reduced mobility $(\mathrm{p}<0.001)$, less autonomy for self-care in oral health and worse oral health. Institutionalized elderly has low functional capacity that is related to several aspects of their lives.
\end{abstract}

Keywords: Aged; Nursing home; Oral health; Disability evaluation.

\section{Resumo}

O objetivo deste estudo foi avaliar a capacidade funcional das pessoas idosas institucionalizadas e verificar quais fatores sociodemográficos, de saúde e de saúde bucal estavam relacionados com a pior capacidade de realizar atividades diárias. Foi realizado um estudo transversal com 512 idosos institucionalizados. Foi avaliado o perfil sociodemográfico; as condições gerais de saúde e de saúde bucal. A capacidade funcional foi avaliada pelo Índice Barthel. Foi encontrada uma alta prevalência de idosos com dependência funcional $(47,1 \%)$. Uma menor capacidade funcional foi associada ao sexo feminino $(p=0,006)$; educação superior $(p=0,009)$; idosos mais velhos $(p<0,045)$; decisão de institucionalização por outros $(\mathrm{p}=0,011)$; estado cognitivo afetado $(\mathrm{p}<0,001)$; mobilidade reduzida $(\mathrm{p}<0,001)$, menor autonomia para o autocuidado da saúde bucal. Os idosos institucionalizados têm baixa capacidade funcional que está relacionada a vários aspectos de suas vidas.

Palavras-chave: Idoso, Instituições de longa permanência para idosos, Saúde bucal; Avaliação da deficiência.

\section{Resumen}

El objetivo de este estudio fue evaluar la capacidad funcional de los ancianos institucionalizados y comprobar qué factores sociodemográficos, sanitarios y de salud bucodental estaban relacionados con la peor capacidad para realizar las actividades diarias. Se realizó un estudio transversal con 512 personas mayores institucionalizadas. Se evaluó el perfil sociodemográfico, la salud general y las condiciones de salud oral. La capacidad funcional se evaluó mediante el índice de Barthel. Se encontró una alta prevalencia de idos con dependencia funcional (47,1\%). La menor 
capacidad funcional se asoció con el sexo femenino ( $\mathrm{p}=0,006)$; la educación superior ( $\mathrm{p}=0,009)$; la edad avanzada $(\mathrm{p}<0,045)$; la decisión de institucionalización por parte de otros $(\mathrm{p}=0,011)$; el estado cognitivo afectado $(\mathrm{p}<0,001)$; la movilidad reducida $(\mathrm{p}<0,001)$, y la menor autonomía para el autocuidado de la salud oral. Los ancianos institucionalizados tienen una baja capacidad funcional que está relacionada con varios aspectos de su vida.

Palabras clave: Anciano; Hogares para ancianos; Salud bucal; Evaluación de la discapacidad.

\section{Introduction}

Reductions in fertility and mortality rates, in addition to scientific and technological advances in health care, have allowed life expectancy to rise (Jerez-Roig et al., 2017), leading to a rapid increase in the world's older population (Janssens et al., 2017; Kuo et al., 2017). The impact of this population ageing has been most pronounced in developing countries, where in the past few years this process has occurred more rapidly than in developed countries (Pinillos-Patiño \& Prieto-Suárez, 2012).

Ageing itself is a common process of human physiology, but it is associated with an increased risk of comorbidities, frailty, and dependence on care (Janssens et al., 2017). Consequently, the family's difficulty in providing care for this population has contributed to the growth in demand for long-stay care institutions for older people (LSCI) (Güths et al., 2017). The older people living in LSCI seem to have a common profile marked by frailty (Fluetti et al., 2018), presence of multimorbidities and polypharmacy (Barros et al., 2016), mobility difficulties (Gonçalves et al., 2010), impairment of cognitive state (Converso \& Iartelli, 2007), and functional capacity (Güths et al., 2017).

The decrease in functional capacity of the institutionalized older adults is manifested in the difficulty of performing their activities of daily living (ADL) and a greater difficulty in exercising their care, which is directly linked to the process of institutionalization (Pinillos-Patiño \& Prieto-Suárez, 2012). With ageing, changes in the ability to perform ADL become an important indicator of the advancement of incapacity in these individuals (Demura et al., 2003).

Functional capacity is also important to the oral health of institutionalized aging adults Dependence for self-care of health is common in the elderly and this contributes to the worsening of oral health and treatment needs, mainly in those more dependent (Hoeksema et al., 2017; Janssens et al., 2017).

Thus, better knowledge of the factors that influence the loss of functional capacity in this population allows actions to be programmed to prevent the loss of autonomy and to stimulate the recovery of lost functions (Cobo, 2014). Therefore, this study evaluated the functional capacity of institutionalized older people and verified which sociodemographic, health factors and oral health were related to the worse ability to perform daily activities.

\section{Methodology}

This article presents results of a quantitative cross-sectional study carried out in the 14 LSCI in Fortaleza, Ceará, Brazil. The target group was the population of 579 older adults who lived in these institutions during April to June 2019. The research was approved by the Research Ethics Committee of the Federal University of Ceará (\#3.009.576).

All residents of the LSCI, aged 60 years or older, were included in the study. The excluded residents were the ones hospitalized or in the process of palliative care, absent from the institutions during the collection period, as well as those in an aggressive and disoriented state, not allowing to perform the exams. Data collection took place in the institutions and was performed by 4 examiners and 4 note takers who underwent a process of training and calibration carried out through the consensus technique. The Kappa indexes obtained demonstrates high agreement among the examiners, 0.80 to 1.00 for interexaminer, and 0.90 to 1.00 for intra-examiner concordances.

Sociodemographic (age, gender, race, time and reason for institutionalization, schooling, health insurance plan holding, retirement pension amount, and who was responsible for the money administration) and health data (functional capacity, the consumption of medicines for continued use, morbidities, cognition, mobility, were collected. 
Functional capacity of the older adults was evaluated through the Barthel Index, which evaluates the degree of assistance required to perform 10 activities of daily living (ADL): personal hygiene, feeding, bathing, toilet use, stair climbing, dressing, bladder control, bowel control, ambulation or wheelchair use, and chair/bed transfers (Mahoney \& Barthel, 1965). The answers receive a score given according to the degree of assistance to perform these ADL that is added together to form a final score ranging from 0 to 100. According to the modified Barthel Index classification (Shah, Vanclay, \& Cooper, 1989), the final scores indicate 'total dependence' (0-25); 'severe dependence' (26-50); 'moderate dependence' (51-75); 'slight dependence' (76-99); 'independence' (100). For analysis purposes, two categories were used: 'independence/slight dependence' and 'total/severe/moderate dependence'.

Cognitive status was evaluated based on the Pfeiffer Test (Pfeiffer, 1975), composed of 10 questions and scored from 0 to 10 according to the number of errors. For this test, the higher the score is, the more preserved the cognitive state of the aging people is. For the data analysis, cognitive status was classified as 1. 'undamaged intellectual function/low cognitive impairment' and 2. 'medium/severe cognitive impairment', whereas mobility was classified in two categories: 1. 'bedridden/ wheelchair user' and 2. 'walking'.

The oral health evaluation was carried out by a questionnaire regarding self-care in oral health and the use of dental services. The oral exams were carried out based on the criteria established by the World Health Organization (WHO, 1998), in which dental caries and periodontal disease were measured by using DMFT index (mean number of decayed, missing, and filled permanent teeth) and the Community Periodontal Index. Edentulism was assessed through the use and need for dental prostheses. Also, the oral mucosa was evaluated and the presence of lesions was recorded according to their condition and location. In order to assess dental functionality, the presence of edentulism, upper and lower shortened dental arch, 2nd and 5th sextants, as well as the number of molars and functional teeth were considered.

Statistical software (SPSS Statistics v22.0) was used for the analysis. It was performed for the characterization of the sample the Pearson's chi-square test or Fisher's exact test and T-test for independent samples $(\alpha=0.05)$. A logistic regression model was performed to identify the sociodemographic and health variables associated with functional capacity.

\section{Results}

From 579 institutionalized older adults, 512 were evaluated, which correspond to $88.4 \%$ of the population. Among the 67 individuals excluded, 40 (59.7\%) did not participate due to refusal, 17 (25.4\%) were hospitalized or in palliative care, and $10(14.9 \%)$ were not in LSCI at the time of application of the research.

The participants were aged between 60 and 110 years, with a mean of $79.3 \pm 9.7$ years. The sample was composed mainly by: women (69.7\%), blacks (50.2\%), and individuals with only primary education (44.8\%). The average time of institutionalization was $6.1 \pm 8.1$ years and $43.9 \%$ were institutionalized by family decision. Most of them no longer maintain contact with the family (67.3\%). Among those who still maintain some kind of family contact, $89.8 \%$ receive visits from their relatives in LSCI. Most participants do not have a health plan insurance (73.7\%), the majority receive retirement pension or some type of benefit $(83.5 \%)$, and $79.8 \%$ of them receive up to 1 minimum wage.

The average Barthel Index was $62.3 \pm 37.7$. Among the participants, $24.4 \%$ presented total dependence; $12.3 \%$, severe dependence; $10.4 \%$, moderate dependence; $30.6 \%$, slight dependence and $22.3 \%$ were classified as independent. After the categorization, $52.9 \%$ were independent/slight dependent whereas $47.1 \%$ were total/severe/moderate dependent. A lower functional capacity was associated with female gender $(\mathrm{p}=0.007)$, age above 80 years $(\mathrm{p}<0.001)$, and institutionalization by family decision $(\mathrm{p}=0.015)$ or due to abandonment/mistreatment $(\mathrm{p}<0.001)$. This association was also observed for those who had contact with the family ( $\mathrm{p}=0.002)$, received more than 1 minimum wage of retirement pension/some benefit ( $\mathrm{p}=0.003$ ), and that the administration of the income was done by the family $(\mathrm{p}<0.001)$ or by LSCI $(\mathrm{p}<0.001)($ Table 1$)$. 
Table 1: Functional capacity according to socio-demographic conditions and general health conditions of institutionalised old people. Fortaleza, Ceará, Brazil, 2019.

\begin{tabular}{|c|c|c|c|c|c|c|}
\hline$x^{2}$ & \multicolumn{2}{|c|}{$\begin{array}{c}\text { Independence / } \\
\text { slight } \\
\text { dependence }\end{array}$} & \multicolumn{2}{|c|}{$\begin{array}{l}\text { Total/severe / } \\
\text { moderate } \\
\text { dependence }\end{array}$} & $P$ value & PR $(95 \%$ CI $)$ \\
\hline Gender & & & & & & \\
\hline $\begin{array}{l}\text { Male } \\
\text { Female }\end{array}$ & $\begin{array}{c}96 \\
175\end{array}$ & $\begin{array}{l}61.9 \\
49.0\end{array}$ & $\begin{array}{c}59 \\
182 \\
\end{array}$ & $\begin{array}{l}38.1 \\
51.0\end{array}$ & 0.007 & $1.26(1.07-1.48)$ \\
\hline Race & & & & & & \\
\hline $\begin{array}{l}\text { White } \\
\text { Black }\end{array}$ & $\begin{array}{l}139 \\
132\end{array}$ & $\begin{array}{l}54.5 \\
51.4\end{array}$ & $\begin{array}{l}116 \\
125\end{array}$ & $\begin{array}{l}45.5 \\
48.6\end{array}$ & 0.476 & $0.94(0.80-1.11)$ \\
\hline Schooling & & & & & & \\
\hline $\begin{array}{l}\text { Illiterate } \\
\text { Primary Education } \\
\text { High school/ Graduate }\end{array}$ & $\begin{array}{c}68 \\
127 \\
73\end{array}$ & $\begin{array}{l}48.9 \\
57.2 \\
54.5\end{array}$ & $\begin{array}{l}71 \\
95 \\
61\end{array}$ & $\begin{array}{l}51.1 \\
42.8 \\
45.5\end{array}$ & $\begin{array}{l}0.124 \\
0.358\end{array}$ & $\begin{array}{l}0.85(0.69-1.04) \\
0.89(0.71-1.13)\end{array}$ \\
\hline Age & & & & & & \\
\hline $\begin{array}{l}\text { Up to } 79 \text { years } \\
80 \text { years or older }\end{array}$ & $\begin{array}{l}160 \\
111\end{array}$ & $\begin{array}{l}61.5 \\
44.0\end{array}$ & $\begin{array}{l}100 \\
141\end{array}$ & $\begin{array}{l}38.5 \\
56.0\end{array}$ & $<0.001$ & $1.39(1.18-1.65)$ \\
\hline Time of institutionalization & & & & & & \\
\hline $\begin{array}{l}\text { Up to } 36 \text { months } \\
\text { Above } 36 \text { months }\end{array}$ & $\begin{array}{l}153 \\
118\end{array}$ & $\begin{array}{l}54.1 \\
51.5\end{array}$ & $\begin{array}{c}141 \\
51\end{array}$ & $\begin{array}{l}45.9 \\
48.5\end{array}$ & 0.568 & $1.04(0.88-1.23)$ \\
\hline Reason for institutionalization & & & & & & \\
\hline $\begin{array}{l}\text { Abandonment / Mistreatment Own } \\
\text { Decision } \\
\text { Family Decision }\end{array}$ & $\begin{array}{c}68 \\
112 \\
85\end{array}$ & $\begin{array}{l}51.5 \\
73.7 \\
38.3 \\
\end{array}$ & $\begin{array}{c}64 \\
40 \\
137 \\
\end{array}$ & $\begin{array}{l}48.5 \\
26.3 \\
61.7\end{array}$ & $\begin{array}{l}<0.001 \\
0.015\end{array}$ & $\begin{array}{l}0.69(0.57-0.84) \\
1.34(1.06-1.70) \\
\end{array}$ \\
\hline Family contact & & & & & & \\
\hline $\begin{array}{l}\text { Contactless } \\
\text { Stay in contact }\end{array}$ & $\begin{array}{l}102 \\
160\end{array}$ & $\begin{array}{l}63.0 \\
47.9\end{array}$ & $\begin{array}{c}60 \\
174\end{array}$ & $\begin{array}{l}37.0 \\
52.1\end{array}$ & 0.002 & $1.40(1.12-1.76)$ \\
\hline Type of family contact & & & & & & \\
\hline $\begin{array}{l}\text { Old adult goes home } \\
\text { Family goes to LSCI } \\
\text { Telephone }\end{array}$ & $\begin{array}{c}16 \\
134 \\
9\end{array}$ & $\begin{array}{l}72.7 \\
44.8 \\
75.0\end{array}$ & $\begin{array}{c}6 \\
165 \\
3\end{array}$ & $\begin{array}{l}27.3 \\
55.2 \\
25.5\end{array}$ & $\begin{array}{l}0.011 \\
0.886\end{array}$ & $\begin{array}{l}2.02(1.05-4.03) \\
1.03(0.68-1.56)\end{array}$ \\
\hline Health insurance plan & & & & & & \\
\hline $\begin{array}{l}\text { Yes } \\
\text { No }\end{array}$ & $\begin{array}{c}65 \\
204 \\
\end{array}$ & $\begin{array}{l}49.2 \\
55.3 \\
\end{array}$ & $\begin{array}{c}67 \\
165 \\
\end{array}$ & $\begin{array}{l}50.8 \\
44.7 \\
\end{array}$ & 0.232 & $0.89(0.73-1.08)$ \\
\hline Retirement pension & & & & & & \\
\hline $\begin{array}{l}\text { Yes } \\
\text { No }\end{array}$ & $\begin{array}{c}223 \\
46\end{array}$ & $\begin{array}{l}52.5 \\
54.8\end{array}$ & $\begin{array}{c}202 \\
38\end{array}$ & $\begin{array}{l}47.5 \\
45.2\end{array}$ & 0.701 & $0.95(0.77-1.13)$ \\
\hline Retirement pension amount & & & & & & \\
\hline $\begin{array}{l}\text { Up to } 1 \text { minimum wage } \\
\text { Above } 1 \text { minimum wage }\end{array}$ & $\begin{array}{c}182 \\
31\end{array}$ & $\begin{array}{l}56.3 \\
37.8 \\
\end{array}$ & $\begin{array}{c}141 \\
51\end{array}$ & $\begin{array}{l}43.7 \\
62.2\end{array}$ & 0.003 & $1.49(1.11-1.99)$ \\
\hline Retirement administration & & & & & & \\
\hline $\begin{array}{l}\text { Old adult } \\
\text { Family } \\
\text { LSCI }\end{array}$ & $\begin{array}{l}95 \\
88 \\
36\end{array}$ & $\begin{array}{l}87.2 \\
40.6 \\
40.0\end{array}$ & $\begin{array}{c}14 \\
129 \\
54\end{array}$ & $\begin{array}{l}12.8 \\
59.4 \\
60.0\end{array}$ & $\begin{array}{l}<0.001 \\
<0.001\end{array}$ & $\begin{array}{l}1.04(0.85-1.26) \\
1.54(1.22-1.95)\end{array}$ \\
\hline $\begin{array}{l}\text { Multi-morbidity } \\
\text { No } \\
\text { Yes }\end{array}$ & $\begin{array}{l}107 \\
164\end{array}$ & $\begin{array}{l}55.4 \\
51.4 \\
\end{array}$ & $\begin{array}{c}86 \\
155 \\
\end{array}$ & $\begin{array}{l}44.6 \\
48.6\end{array}$ & 0.376 & $1.07(0.91-1.27)$ \\
\hline $\begin{array}{l}\text { Polipharmacy } \\
\text { Yes } \\
\text { No }\end{array}$ & $\begin{array}{l}177 \\
94\end{array}$ & $\begin{array}{l}54.5 \\
50.3 \\
\end{array}$ & $\begin{array}{c}148 \\
93\end{array}$ & $\begin{array}{l}45.5 \\
49.7 \\
\end{array}$ & 0.360 & $1.08(0.91-1.28)$ \\
\hline $\begin{array}{l}\text { Cognitive State } \\
\text { Undamaged function and low cognitive } \\
\text { impairment } \\
\text { Medium and severe cognitive impairment }\end{array}$ & $\begin{array}{l}154 \\
117\end{array}$ & $\begin{array}{l}83.7 \\
35.7\end{array}$ & $\begin{array}{l}30 \\
211\end{array}$ & $\begin{array}{l}16.3 \\
64.3 \\
\end{array}$ & $<0.001$ & $2.34(2.00-2.75)$ \\
\hline
\end{tabular}




\begin{tabular}{l|cccc|c|c|} 
Mobility & & & & & & \\
Bedridden / wheelchair user Walking & 6 & 4.0 & 145 & 96.0 & $<0.001$ & $0.05(0.02-0.11)$ \\
\hline
\end{tabular}

LSCI: Long-stay care institutions for older people; PR: prevalence ratios; 95\% CI: 95\% Confidence interval. Source: Authors.

Regarding health data, $62.3 \%$ of the older adults had multi-morbidity and $63.5 \%$ of them made use of polypharmacy. Concerning the cognitive state, $46.3 \%$ presented several cognitive impairment; $17.8 \%$, moderate cognitive impairment; $14.2 \%$, low cognitive impairment; and 21.7\%, undamaged intellectual function. Regarding mobility, $11.9 \%$ were bedridden, $17.6 \%$ were wheelchair users, $25.6 \%$ walked with help and $44.7 \%$ could walk without help. Table 1 shows that a lower functional capacity was associated with worse cognition levels $(\mathrm{p}<0.000)$ and mobility conditions $(\mathrm{p}<0.000)$.

The logistic regression model of the variables associated with functional capacity is shown in Table 2. Among the sociodemographic aspects, those associated with lower functional capacity were: the female gender $(P R=2.36, p=0.006)$, the higher level of schooling (high school/graduation completed) (PR=2.28, p=0.009), and when the decision for institutionalization is made by others $(\mathrm{PR}=2.25, \mathrm{p}=0.011)$, concerning to the age, it was found that for every 1 year of life, the chances of being more dependent increase 1.03 times $(\mathrm{p}=0.045)$. Among the health variables, those associated with a lower functional capacity were: the worst degree of cognition state $(\mathrm{PR}=6.67, \mathrm{p}<0.001)$; and bedridden or wheelchair users $(\mathrm{PR}=90.16, \mathrm{p}<0.001)$.

Table 2: Model of logistic regression of functional capacity according to socio-demographic conditions and general health conditions of institutionalised older people. Fortaleza, Ceará, Brazil, 2019.

\begin{tabular}{l|c|c|c|c}
\hline & $\begin{array}{c}\mathbf{p} \\
\text { value }\end{array}$ & PR (95\% CI) & $\begin{array}{c}\text { p value } \\
\text { adjuested }\end{array}$ & PRa (95\% CI) \\
\hline Female gender & 0.007 & $1.26(1.07-1.48)$ & 0.006 & $2.36(1.27-4.37)$ \\
\hline Black older adult & 0.476 & $0.94(0.80-1.11)$ & 0.510 & $0.83(0.48-1.42)$ \\
\hline Higher level of schooling & 0.358 & $0.89(0.71-1.13)$ & 0.009 & $2.28(1.23-4.24)$ \\
\hline Get older (per year) & $<0.001$ & $1.39(1.18-1.65)$ & 0.045 & $1.03(1.00-1.06)$ \\
\hline Institutionalization time (years) & 0.568 & $1.04(0.88-1.23)$ & 0.133 & $0.99(0.99-1.00)$ \\
\hline $\begin{array}{l}\text { Decision for institutionalization is } \\
\text { made by others }\end{array}$ & $<0.001$ & $0.69(0.57-0.84)$ & 0.011 & $2.25(1.20-4.22)$ \\
\hline Without multi-morbidities & 0.376 & $1.07(0.91-1.27)$ & 0.638 & $0.87(0.50-1.51)$ \\
\hline Worst affected cognitive state & $<0.001$ & $2.34(2.00-2.75)$ & $<0.001$ & $6.67(3.50-12.71)$ \\
\hline Bedridden or wheelchair user & $<0.001$ & $0.05(0.02-0.11)$ & $<0.001$ & $90.16(33.47-242.91)$ \\
\hline
\end{tabular}

PR: prevalence ratios; PRa: adjuested prevalence ratios; 95\% CI: 95\% Confidence interval. Source: Authors.

The variables of self-care in oral health and use of dental services associated with functional capacity can be seen in Table 3. It was observed that autonomy for brushing teeth and gums $(\mathrm{p}<0.001)$ and for sanitizing prostheses $(\mathrm{p}<0.001)$, greater frequency of brushing $(\mathrm{p}=0.008)$ and removal of the prosthesis before sleeping $(\mathrm{p}=0.001)$ were associated with higher levels of functional capacity. Concerning the use of dental services, it was observed that older adults with better functional capacity have been to the dentist for more than one year $(\mathrm{p}=0.012)$; looked for the service due to treatment need $(\mathrm{p}<0.001)$ or pain $(\mathrm{p}=0.023)$; and were attended in a private service $(\mathrm{p}<0.001)$. 
Table 3: Self-care in oral health and use of oral health services according to the functional capacity of the institutionalized older people. Fortaleza, Ceará, Brazil, 2019.

\begin{tabular}{|c|c|c|c|c|c|c|}
\hline & \multicolumn{2}{|c|}{$\begin{array}{l}\text { Independence / } \\
\text { slight } \\
\text { dependence }\end{array}$} & \multicolumn{2}{|c|}{$\begin{array}{l}\text { Total / severe / } \\
\text { moderate } \\
\text { dependence }\end{array}$} & \multirow[t]{2}{*}{$\begin{array}{c}\mathbf{P} \\
\text { value }\end{array}$} & \multirow[t]{2}{*}{ PR (95\% CI) } \\
\hline & $\mathbf{N}$ & $\%$ & $\mathbf{N}$ & $\%$ & & \\
\hline $\begin{array}{l}\text { Autonomy for brushing teeth and gums } \\
\text { Yes } \\
\text { No } \\
\text { Do not brush }\end{array}$ & $\begin{array}{c}206 \\
29 \\
36 \\
\end{array}$ & $\begin{array}{l}79.8 \\
15.3 \\
56.3 \\
\end{array}$ & $\begin{array}{c}52 \\
161 \\
28 \\
\end{array}$ & $\begin{array}{l}20.2 \\
84.7 \\
43.7 \\
\end{array}$ & $\begin{array}{l}<0.001 \\
<0.001 \\
\end{array}$ & $\begin{array}{l}5.23(3.72-7.35) \\
2.17(1.50-3.13)\end{array}$ \\
\hline $\begin{array}{l}\text { Frequency of brushing teeth and gums } \\
1 \text { time a day } \\
2 \text { times a day or more }\end{array}$ & $\begin{array}{c}63 \\
172 \\
\end{array}$ & $\begin{array}{l}43.4 \\
56.8 \\
\end{array}$ & $\begin{array}{c}82 \\
131 \\
\end{array}$ & $\begin{array}{l}56.6 \\
43.2 \\
\end{array}$ & 0.008 & $1.30(1.07-1.58)$ \\
\hline $\begin{array}{l}\text { Autonomy for sanitizing the prosthesis } \\
\text { Yes } \\
\text { No }\end{array}$ & $\begin{array}{c}124 \\
9 \\
\end{array}$ & $\begin{array}{l}83.8 \\
16.1 \\
\end{array}$ & $\begin{array}{l}24 \\
47 \\
\end{array}$ & $\begin{array}{l}16.2 \\
83.9 \\
\end{array}$ & $<0.001$ & $5.21(2.85-9.52)$ \\
\hline $\begin{array}{l}\text { Frequency of sanitizing the prosthesis } \\
1 \text { time a day } \\
2 \text { times a day or more }\end{array}$ & $\begin{array}{c}20 \\
113 \\
\end{array}$ & $\begin{array}{l}60.6 \\
66.1 \\
\end{array}$ & $\begin{array}{l}13 \\
58 \\
\end{array}$ & $\begin{array}{l}39.4 \\
33.9 \\
\end{array}$ & 0.555 & $0.91(0.68-1.23)$ \\
\hline $\begin{array}{l}\text { Removal of the prosthesis before sleeping } \\
\text { Always / sometimes } \\
\text { Never }\end{array}$ & $\begin{array}{l}75 \\
58 \\
\end{array}$ & $\begin{array}{l}76.5 \\
54.7 \\
\end{array}$ & $\begin{array}{l}23 \\
48 \\
\end{array}$ & $\begin{array}{l}23.5 \\
45.3 \\
\end{array}$ & 0.001 & $1.39(1.13-1.71)$ \\
\hline $\begin{array}{l}\text { Last time at the dentist } \\
\text { More than } 1 \text { year ago } \\
\text { Less than } 1 \text { year ago }\end{array}$ & $\begin{array}{c}111 \\
76 \\
\end{array}$ & $\begin{array}{l}65.7 \\
51.7 \\
\end{array}$ & $\begin{array}{l}58 \\
71 \\
\end{array}$ & $\begin{array}{l}34.3 \\
48.3 \\
\end{array}$ & 0.012 & $1.40(1.07-1.83)$ \\
\hline $\begin{array}{l}\text { Reason for going to the dentist last time } \\
\text { Prevention } \\
\text { Need for Treatment } \\
\text { Pain }\end{array}$ & $\begin{array}{l}58 \\
86 \\
21\end{array}$ & $\begin{array}{l}45.0 \\
73.5 \\
67.7 \\
\end{array}$ & $\begin{array}{l}71 \\
31 \\
10 \\
\end{array}$ & $\begin{array}{l}55.0 \\
26.5 \\
32.3\end{array}$ & $\begin{array}{l}<0.001 \\
0.023\end{array}$ & $\begin{array}{l}0.61(0.49-0.76) \\
0.58(0.34-0.99)\end{array}$ \\
\hline $\begin{array}{l}\text { Type of dentist service } \\
\text { Private } \\
\text { Public } \\
\text { Offered by LSCI } \\
\end{array}$ & $\begin{array}{l}69 \\
61 \\
55 \\
\end{array}$ & $\begin{array}{l}69.7 \\
67.0 \\
45.1 \\
\end{array}$ & $\begin{array}{l}30 \\
30 \\
67 \\
\end{array}$ & $\begin{array}{l}30.3 \\
33.0 \\
54.9 \\
\end{array}$ & $\begin{array}{c}0.693 \\
<0.001 \\
\end{array}$ & $\begin{array}{l}1.04(0.85-1.26) \\
1.54(1.22-1.95) \\
\end{array}$ \\
\hline
\end{tabular}

LSCI: Long-stay care institutions for older people; PR: prevalence ratios; 95\% CI: 95\% Confidence interval. Source: Authors.

Table 4 shows the association of caries and periodontal disease with the functional capacity of the participants. It was found that those with lower functional capacity had higher DMFT index $(\mathrm{p}=0.004)$, few healthy teeth $(\mathrm{p}=0.005)$, more teeth lost $(\mathrm{p}=0.009)$, fewer molars $(\mathrm{p}=0.019)$, more sextants excluded $(\mathrm{p}=0.015)$, and fewer exposed roots $(\mathrm{p}=0.037)$. 
Table 4: Functional capacity according to the mean and standard deviation of caries and periodontal disease conditions of institutionalised older people. Fortaleza, Ceará, Brazil, 2019.

\begin{tabular}{|c|c|c|c|c|c|}
\hline & \multicolumn{2}{|c|}{$\begin{array}{c}\text { Independence / slight } \\
\text { dependence }\end{array}$} & \multicolumn{2}{|c|}{$\begin{array}{c}\text { Total / severe / } \\
\text { moderate dependence }\end{array}$} & \multirow[t]{2}{*}{$P$ value } \\
\hline & Mean & SD & Mean & SD & \\
\hline DMFT Index & 28.9 & 5.2 & 30.1 & 3.9 & 0.004 \\
\hline Number of missing teeth & 26.9 & 7.5 & 28.5 & 6.0 & 0.009 \\
\hline Number of healthy teeth & 2.7 & 4.6 & 1.6 & 3.5 & 0.005 \\
\hline Number of molars & 0.9 & 1.7 & 0.5 & 1.4 & 0.019 \\
\hline Number of decayed roots & 0.6 & 1.7 & 0.5 & 1.6 & 0.897 \\
\hline Number of exposed roots & 2.5 & 4.3 & 1.7 & 3.4 & 0.037 \\
\hline Sextants with dental calculus & 0.6 & 1.3 & 0.5 & 1.2 & 0.185 \\
\hline Sextants with bleeding on probing & 0.8 & 1.4 & 0.6 & 1.4 & 0.174 \\
\hline Sextants with shallow pocket & 0.3 & 0.8 & 0.2 & 0.7 & 0.230 \\
\hline Sextants with deep pocket & 0.1 & 0.4 & 0.1 & 0.3 & 0.820 \\
\hline Excluded sextant & 4.9 & 1.7 & 5.3 & 1.5 & 0.015 \\
\hline
\end{tabular}

DMFT: Decayed, Missing, and Filled Permanent Teeth; SD: Standard deviation. Source: Authors.

It was also identified an association between worse functional capacity with no use of upper $(\mathrm{p}<0.001)$ and lower $(\mathrm{p}=0.011 ; \mathrm{p}=0.045)$ prosthesis, as well as the need for oral rehabilitation through lower complete denture $(\mathrm{p}=0.021)($ Table 5$)$. Regarding dental functionality, the presence of up to 19 teeth in the mouth $(p=0.042)$, edentulism $(p=0.017)$, and absence of short dental arch in at least one arch $(\mathrm{p}=0.013)$ were also associated with a worse functional capacity (Table 5).

Table 5: Functional capacity according to the conditions of use of prosthesis, need for oral rehabilitation, oral lesions and dental functionality of institutionalised older people. Fortaleza, Ceará, Brazil, 2019.

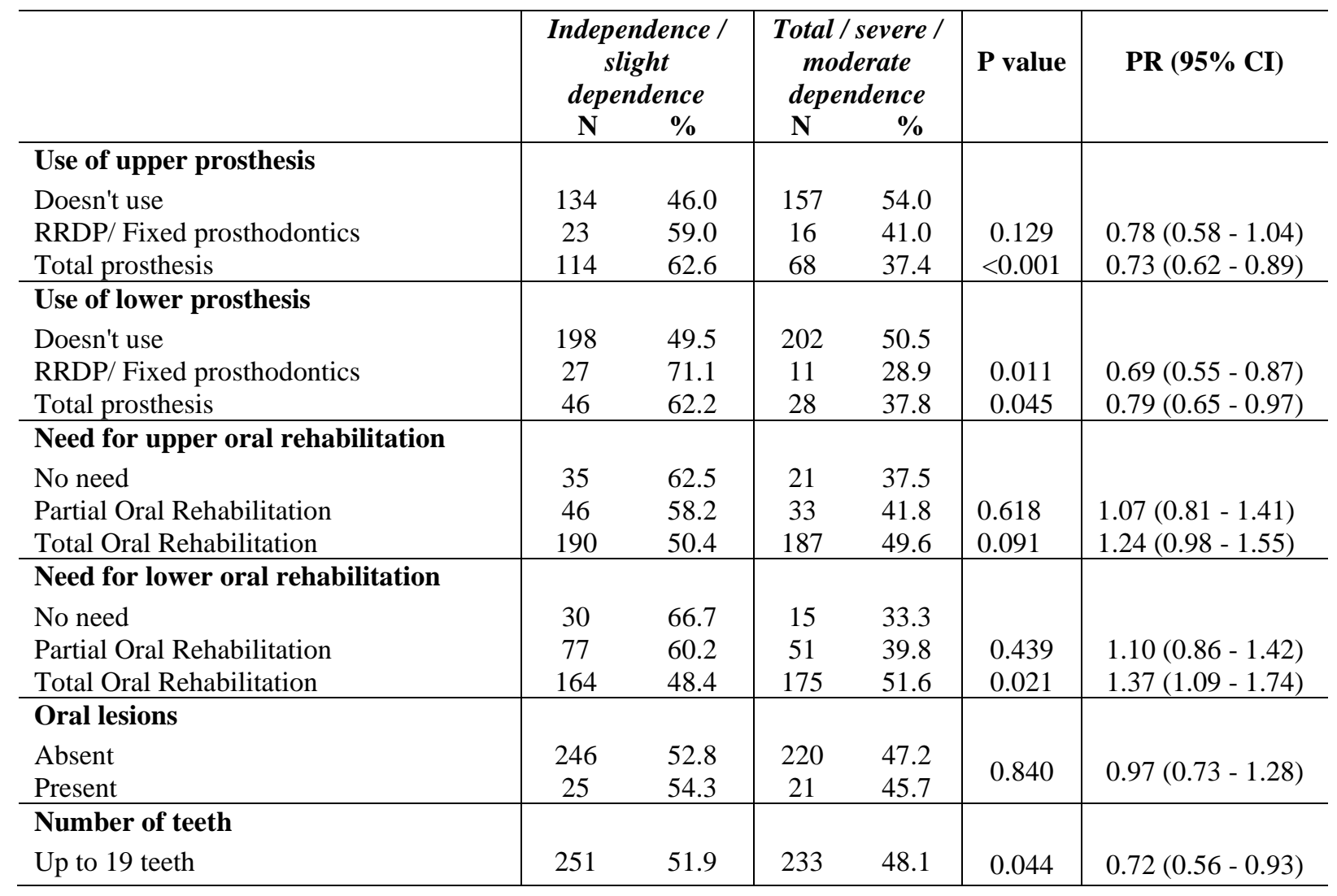




\begin{tabular}{l|cc|cc|c|c}
20 teeth or more & 20 & 71.4 & 8 & 28.6 & & \\
\hline Total Edentulism & & & & & & \\
No & 116 & 58.6 & 82 & 41.4 & \multirow{2}{*}{0.042} & $1.18(1.00-1.39)$ \\
\hline Yes & 155 & 49.4 & 159 & 50.6 & & \\
\hline Presence of 2nd and 5th Sextant & & & & & & \\
Both absent & 249 & 52.5 & 225 & 47.5 & \multirow{2}{*}{0.524} & $0.90(0.68-1.20)$ \\
At least one present. & 22 & 57.9 & 16 & 42.1 & & \\
\hline Presence of shortened dental arch & & & & & & \\
Absent & 246 & 51.5 & 232 & 48.5 & 0.013 & $0.70(0.56-0.87)$ \\
Present in at least 1 arcade & 25 & 73.5 & 9 & 26.5 & \\
\hline
\end{tabular}

RRDP: removable partial denture prosthesis; PR: prevalence ratios; 95\% CI: 95\% Confidence interval. Source: Authors.

\section{Discussion}

The mean Barthel Index found in the present study (62.3) was within the values range presented in the literature (20.980.0) (Converso \& Iartelli, 2007; Fluetti et al., 2018; Khanagar et al., 2015; Kuo et al., 2017; Nihtilä et al., 2017). When it comes to the level of assistance required to perform activities of daily living, the percentage of moderate to complete dependence found was $47.1 \%$, a value that also shows to be quite variable in the literature $10.4-66.0 \%$ (Converso \& Iartelli, 2007; de Medeiros et al., 2019; Ferreira et al., 2019; Freitas et al., 2016; Jerez-Roig et al., 2017; Nihtilä et al., 2017; PinillosPatiño \& Prieto-Suárez, 2012). It is believed that these variations are mainly due to the sociodemographic characteristics of the older adults included in the study samples, in addition to the influence of the institution profile in the process of physical domination by the residents themselves. This structural influence of the institution is relevant to the quality of life of the older adults due to the stimulus to their independence (Oliveira \& Júnior, 2014).

There was also a predominance of females in this study, which was associated with a higher degree of dependence in the sample. Literature is unanimous in stating that most of the institutionalized older adult population is female (Demura et al., 2003; Fluetti et al., 2018; Güths et al., 2017; Portella et al., 2015), and this can be explained by the greater longevity of women (Fluetti et al., 2018). Thus, because they live longer, women have a greater chance of becoming dependent on care over time, which may result in their institutionalization due to this.

It was observed that older adults with a high education had worse functional capacity, which suggest that older people with higher education seek LSCI when they are already with reduced functional capacity, and institutionalization can be a solution for their relatives in relation to their care, regardless of their own will. On the other hand, considering that schooling is an indicator of socioeconomic condition, it is possible that the older adults with less schooling opt for institutionalization as an alternative to improve their living conditions such as housing, food, and basic care.

Another factor associated with lower functional capacity was older age. Although age itself is not a determining factor for the decrease in functional capacity, health conditions worsen as age advances (Vivian \& Argimon, 2009). Longitudinal studies explain that this condition is due to the fact that older age is a significant factor in the deterioration of physical functioning (Kuo et al., 2017), besides being crucial for increased difficulty in performing ADL (Gill et al., 2009). Thus, people's activity levels may deteriorate with age, causing their functional capacity to decrease as well.

The reason for institutionalization by decision of third parties was also associated with a reduced functional capacity in older adults. The deterioration caused by the ageing process reduces the functional capacity, cognitive state, and psychic capacity of these individuals, leading them to need more care and attention (Fluetti et al., 2018). This condition, when added to the reduction in the number of family caregivers (Güths et al., 2017), may increase the chances of older people with less functional capacity to be institutionalized. In addition, the health deterioration caused by abandonment and mistreatment 
increases even more the need for care, which may end up resulting in a law intervention and making institutionalization mandatory.

In contrast, most of the participants who have been institutionalized by their own decision are more independent, showing that, in most of these cases, functional capacity may not have influenced the decision to become institutionalized. This fact can be explained by the important relationship between autonomy and independence of older adults (Cobo, 2014), since the more independent they are, the more able they are to exercise their autonomy and to decide by themselves.

The decrease of the cognitive state is pointed as a significant risk factor for a worsening in the functional capacity of the institutionalized older adults (Jerez-Roig et al., 2017; Kuo et al., 2017). It should be noted that approximately 64.1\% of our sample presented moderate or severe cognitive impairment. The high prevalence of individuals with cognitive deficit in LSCI is due to the fact that this condition demands a greater need for care (Güths et al., 2017), leading the majority of them to be institutionalized. Therefore, this high prevalence of individuals with affected cognition status reflected in a greater difficulty in performing their ADL.

The worst mobility conditions, were also associated with reduced functional capacity. Having the mobility impaired can affect the performance of certain activities due to loss of physical conditioning, muscle atrophy, deficit of balance, and dependence for the performance of these activities (Ferreira et al., 2019). This weakness is shown as an important health marker for older adults because it influences directly in the decrease of their functional capacity (Fluetti et al., 2018).

Regarding self-care in oral health, it was found that the lack of brushing or autonomy to perform it was linked to a lower functional capacity. Since these older adults do not have autonomy to perform their ADL, they are unable to take care of their own oral health (Chiesi et al., 2019). It is also necessary to emphasize that the use of toothbrushes for cleaning remaining teeth and dental prostheses can be a real challenge for older people who perform their own self-care of oral hygiene (Portella et al., 2015), making the use of these devices more difficult in more incapacitating situations.

Considering the older adults compromised functional capacity and the impossibility of correctly managing their own oral hygiene, oral care procedures fall on the caregiver. However, oral hygiene is considered a problematic activity for these professionals due to non-cooperative older adults, the difficulty to deal with the routine and tasks to be performed (Lantto, Lundqvist, \& Wårdh, 2018), the lack of both oral hygiene material in LSCI and knowledge of the caregiver to perform it (Khanagar et al., 2015). Caregivers are the main actors in improving oral health care for these older people, and may promote better results for this population if they are better trained (Khanagar et al., 2015). Studies that evaluated the improvement in oral health care for this population after training with the caregivers proved that older adults had better care with (Nihtilä et al., 2017), and improvement in the oral hygiene parameters assessed (Portella et al., 2015).

Worse oral health conditions were observed in older adults with lower functional capacity, a fact confirmed by previous studies (Chiesi et al., 2019; de Medeiros et al., 2019; Lantto et al., 2018; Nihtilä et al., 2017). Moreover, the inability to take care of their oral hygiene and resistance to dental treatment are pointed out as the main reasons for increased risk of developing oral diseases and dental loss in institutionalized older people with lower functional capacity (Lantto et al., 2018; Nihtilä et al., 2017). In addition, it should be noted that all oral parameters and dental functionality indicators that were associated with lower functional capacity are related to edentulism. Thus, it is noticeable that there was a close relationship between tooth loss and lower functional capacity, showing that a worse oral health condition occurs in older adults with lower ability to perform their ADL.

Another found was the fact that older adults do not wear prostheses was also associated with a worse functional capacity. This can be explained by the possibility of older adults with better functional capacity to be able to wear prostheses, to perform their own oral hygiene care, and to be aware of their oral health condition (de Medeiros et al., 2019). Another explanation for this is the possibility that these prostheses were removed by caregivers from individuals with low functional 
capacity in order to reduce the oral health care provided to them (de Medeiros et al., 2019), or by themselves as their functional capacity decreased, due to their difficulty of wearing those prostheses compared to the ones supported by teeth or implants (Lantto et al., 2018).

A lower functional capacity was also associated with the need for lower complete dentures. It can be explained by the difficulty of using this type of prosthesis, which can be more challenging in cases of older adults more dependent on care. It should also be noted that the treatment needs of patients with lower functional capacity are not met with the same pattern as the general populations. This situation occurs mainly due to the difficulty these population have to express their need for treatment (Lantto et al., 2018), since they have a lower awareness of their oral condition (de Medeiros et al., 2019), which makes them seek dental service less or only when they are confronted with some health problem (Montal et al., 2006).

Older adults with better functional capacity used the dental service for reasons of treatment or pain. The fact that they have more teeth and greater autonomy to choose when they want to go to the dentist, as well as to understand better their oral health needs in case of pain, may have influenced this finding. However, an association was found between a worse functional capacity and the last contact with the dentist having been performed in LSCI, for prevention reasons, and in a shorter time. We believe this finding was due to the fact that most LSCI included have partnership with universities, receiving students who develop oral health promotion activities with these older adults. Therefore, the attention people with less functional capacity is probably being prioritized in comparison to those who are more independent.

The association of oral health conditions and functional capacity of institutionalized older adults play an important role in understanding the factors related to dental care of these population (Freitas et al., 2016). Even in view of the poor oral health conditions found, the design of our study does not allow us to state whether these oral health conditions are previous or the process of institutionalization exacerbated them. Even so, the oral health care of these older adults is necessary since their oral health is likely to deteriorate further with the institutionalization process due to increased dependence on care over time and the subsequent neglect of oral health.

The literature demonstrates the progressive and exponential decline in functional capacity as a result of the process of institutionalization (Jerez-Roig et al., 2017). Also, the probability of more independent older adults do not suffer this decline drops to only $44 \%$ after 24 months of institutionalization (Jerez-Roig et al., 2017). Besides, the prevalence of dependence for ADL in this population is up to 6.4 times higher than that observed in the community (Fluetti et al., 2018; Oliveira \& Mattos, 2012). Other authors also show a clear relationship between institutionalization, autonomy, and quality of life of these individuals, that may decrease after a few months of institutionalization (Castro-Monteiro et al., 2014; Cobo, 2014).

Some limitations were identified in this study, such as the possible memory bias and the difficulty of collecting information due to differences in the medical records and/or lack of information reported in those documents. The use of the Pfeiffer test, due to its quick and easy application, may have underestimated some cases of affected cognition as a result of the low complexity of the questions. Another limitation is the study design that, because it is a cross-sectional study, causality cannot be determined, yet joint modeling with longitudinal analysis and survival analysis is still of interest and can be used in future studies. The fact of having covered almost the entire LSCI population in Fortaleza increases the reliability and external validity of the findings due to the representativeness of the institutionalized older adults in that city. Even so, generalizations for other populations should be viewed with caution, because the influence of regional and cultural aspects, as well as the characteristics of the older adults themselves should be taken into account.

\section{Conclusion}

The present study showed that most of institutionalized older adults had some kind of limitation in their functional capacity. The greatest limitation to perform their activities of daily living was associated with socioedemographic factors such 
as female sex, higher education, advanced age, and decision to institutionalize made by others. Also, lower level of cognition state, mobility limitations, lower oral self-care, and worse oral health conditions were associated with worse levels of functional capacity. Given these findings, it is suggested the development of better health care by stimulating a more active life for older adults and training of caregivers, so as to reduce the aggravation of these institutionalized older people and the negative impact of these factors on the difficulty of performing their activities of daily living.

\section{Acknowledgments}

We are grateful to the Coordenação de Aperfeiçoamento de Pessoal de Nível Superior (CAPES) e and Fundação Cearense de Apoio ao Desenvolvimento Científico e Tecnológico (FUNCAP that financed the scholarship that allowed the development of this research and the institutions and older adults who participated in it.

\section{References}

Barros, T. V. P., Santos, A. D. B., Gonzaga, J. D. M., Lisboa, M. G. D. C., \& Brand, C. (2016). Capacidade funcional de idosos institucionalizados: revisão integrativa. ABCS Health Sciences, 41(3), 176-180. https://doi.org/10.7322/abcshs.v41i3.908

Castro-Monteiro, E., Forjaz, M. J., Ayala, A., Rodriguez-Blazquez, C., Fernandez-Mayoralas, G., Diaz-Redondo, A., \& Martinez-Martin, P. (2014). Change and predictors of quality of life in institutionalized older adults with dementia. Quality of Life Research, 23(9), 2595-2601. https://doi.org/10.1007/s11136014-0706-8

Chiesi, F., Grazzini, M., Innocenti, M., Giammarco, B., Simoncini, E., Garamella, G., ... Bonaccorsi, G. (2019). Older People Living in Nursing Homes: An Oral Health Screening Survey in Florence, Italy. International Journal of Environmental Research and Public Health, 16(18), 3492. https://doi.org/10.3390/ijerph16183492

Cobo, C. M. S. (2014). The influence of institutionalization on the perception of autonomy and quality of life in old people. Revista Da Escola de Enfermagem, 48(6), 1011-1017. https://doi.org/10.1590/S0080-623420140000700008

Converso, M. E., \& Iartelli, I. (2007). Caracterização e análise do estado mental e funcional de idosos institucionalizados em instituições públicas de longa permanência. Jornal Brasileiro de Psiquiatria, 56(4), 267-272. https://doi.org/10.1590/S0047-20852007000400005

Demura, S., Sato, S., Minami, M., \& Kasuga, K. (2003). Gender and age differences in basic ADL ability on the elderly: Comparison between the independent and the dependent elderly. Journal of Physiological Anthropology and Applied Human Science, 22(1), 19-27. https://doi.org/10.2114/jpa.22.19

Ferreira, L. M. de B. M., Ribeiro, K. M. O. B. de F., Jerez-Roig, J., Araújo, J. R. T., \& de Lima, K. C. (2019). Recurrent falls and risk factors among institutionalized older people. Ciencia e Saude Coletiva, 24(1), 67-75. https://doi.org/10.1590/1413-81232018241.35472016

Fluetti, M. T., Fhon, J. R. S., Oliveira, A. P. de, Chiquito, L. M. O., \& Marques, S. (2018). The frailty syndrome in institutionalized elderly persons. Revista Brasileira de Geriatria e Gerontologia, 21(1), 60-69. https://doi.org/10.1590/1981-22562018021.170098

Freitas, Y. N., Lima, K. C., \& da Silva, D. A. (2016). Condições de saúde bucal e capacidade funcional em idosos: Um estudo longitudinal de base populacional. Revista Brasileira de Epidemiologia, 19(3), 670-674. https://doi.org/10.1590/1980-5497201600030016

Gill, T. M., Gahbauer, E. A., Han, L., \& Allore, H. G. (2009). Functional trajectories in older persons admitted to a nursing home with disability after an acute hospitalization. Journal of the American Geriatrics Society, 57(2), 195-201. https://doi.org/10.1111/j.1532-5415.2008.02107.x

Gonçalves, L. H. T., da Silva, A. H., Mazo, G. Z., Bertoldo Benedetti, T. R., dos Santos, S. M. A., Marques, S., ... Rezende, T. de L. (2010). O idoso institucionalizado: Avaliação da capacidade funcional e aptidão física. Cadernos de Saude Publica, 26(9), 1738-1746. https://doi.org/10.1590/s0102$311 \times 2010000900007$

Güths, J. F. da S., Jacob, M. H. V. M., Santos, A. M. P. V. dos, Arossi, G. A., \& Béria, J. U. (2017). Perfil sociodemográfico, aspectos familiares, percepção de saúde, capacidade funcional e depressão em idosos institucionalizados no Litoral Norte do Rio Grande do Sul, Brasil. Revista Brasileira de Geriatria e Gerontologia, 20(2), 175-185. https://doi.org/10.1590/1981-22562017020.160058

Hoeksema, A. R., Peters, L. L., Raghoebar, G. M., Meijer, H. J. A., Vissink, A., \& Visser, A. (2017). Oral health status and need for oral care of caredependent indwelling elderly: from admission to death. Clinical Oral Investigations, 21(7), 2189-2196. https://doi.org/10.1007/s00784-016-2011-0

Janssens, B., Vanobbergen, J., Petrovic, M., Jacquet, W., Schols, J. M. G. A., \& Visschere, L. De. (2017). The oral health condition and treatment needs of nursing home residents in Flanders (Belgium). Community Dental Health, 34, 143-151. https://doi.org/10.1922/CDH

Jerez-Roig, J., De Brito MacEdo Ferreira, L. M., De Araújo, J. R. T., \& Lima, K. C. (2017). Functional decline in nursing home residents: A prognostic study. PLoS ONE, 12(5), 1-14. https://doi.org/10.1371/journal.pone.0177353

Khanagar, S., Naganandini, S., Rajanna, V., Naik, S., Rao, R., \& Madhuniranjanswamy, M. S. (2015). Oral hygiene status of institutionalised dependent elderly in India - A cross-sectional survey. Canadian Geriatrics Journal, 18(2), 51-56. https://doi.org/10.5770/cgj.18.147

Kuo, H. T., Lin, K. C., Lan, C. F., \& Li, I. C. (2017). Activities of daily living trajectories among institutionalised older adults: A prospective study. Journal of 
Clinical Nursing, 26(23-24), 4756-4767. https://doi.org/10.1111/jocn.13828

Lantto, A., Lundqvist, R., \& Wårdh, I. (2018). Oral Status and Prosthetic Treatment Needs in Functionally Impaired and Elderly Individuals. The International Journal of Prosthodontics, 31(5), 494-501. https://doi.org/10.11607/ijp.5491

Mahoney, F. I., \& BARTHEL, D. W. (1965). Functional evaluation: the Barthel Index. Md State Med J, 14, 61-65.

Medeiros, A. K. B., Barbosa, F. P., Piuvezam, G., Carreiro, A. da F. P., \& Lima, K. C. (2019). Prevalence and factors associated with alterations of the temporomandibular joint in institutionalized elderly. Ciencia e Saude Coletiva, 24(1), 159-168. https://doi.org/10.1590/1413-81232018241.06132017

Montal, S., Tramini, P., Triay, J. A., \& Valcarcel, J. (2006). Oral hygiene and the need for treatment of the dependent institutionalised elderly. Gerodontology, 23(2), 67-72. https://doi.org/10.1111/j.1741-2358.2006.00111.x

Nihtilä, A., Tuuliainen, E., Komulainen, K., Autonen-Honkonen, K., Nykänen, I., Hartikainen, S., ... Suominen, A. L. (2017). Preventive oral health intervention among older home care clients. Age and Ageing, 46(5), 846-851. https://doi.org/10.1093/ageing/afx020

Oliveira, J. R. de, \& Júnior, P. R. R. (2014). Avaliação da qualidade de vida e capacidade funcional de idosos institucionalizados. Revista Kairós Gerontologia, 1(3), 343-353.

Oliveira, P. H. de, \& Mattos, I. E. (2012). Prevalência e fatores associados à incapacidade funcional em idosos institucionalizados no Município de Cuiabá, Estado de Mato Grosso, Brasil, 2009-2010. Epidemiologia e Serviços de Saúde, 21(3), 395-406. https://doi.org/10.5123/s1679-49742012000300005

Pfeiffer, E. (1975). A short portable mental status questionnaire for the assessment of organic brain deficit in elderly patients. Geriatr Soc., $23(10), 433-441$.

Pinillos-Patiño, Y., \& Prieto-Suárez, E. (2012). Funcionalidad física de personas mayores institucionalizadas y no institucionalizadas en Barranquilla, Colombia. Revista de Salud Pública (Bogotá, Colombia), 14(3), 438-447.

Portella, F. F., Rocha, A. W., Haddad, D. C., Fortes, C. B. B., Hugo, F. N., Padilha, D. M. P., \& Samuel, S. M. W. (2015). Oral hygiene caregivers' educational programme improves oral health conditions in institutionalised independent and functional elderly. Gerodontology, 32(1), 28-34. https://doi.org/10.1111/ger.12049

Shah, S., Vanclay, F., \& Cooper, B. (1989). Improving the sensitivity of the Barthel Index for stroke rehabilitation. J Clin Epidemiol, 42(8), 703-709. https://doi.org/10.1016/0550-3213(73)90429-X

Vivian, A. de S., \& Argimon, I. I. de L. (2009). Estratégias de enfrentamento, dificuldades funcionais e fatores associados em idosos institucionalizados. Cadernos de Saude Publica, 25(2), 436-444. https://doi.org/10.1590/s0102-311x2009000200022

WHO, (1998). Oral Health Surveys: Basic Methods. Geneva. 